\title{
Introduction
}

\section{Real and financial aspects of financial integration}

In the last two decades we have seen both beneficial and deleterious effects of enhanced global financial and real integration. While the introduction of the Euro, the widening and deepening of the EU and the success of NAFTA are uncontested, there have also been significant episodes of crisis and contagion, such as the Asian, Brazilian and Russian crises, which have generated debate and diverse opinion. These events have stimulated an abundant literature on the measurement and econometric investigation of spillovers, contagion and integration.

This special issue of the Quarterly Review of Economics and Finance addresses the issue of the real and financial aspects of financial integration. The papers are drawn from those presented at the 3rd INFINITI conference on International Financial Integration, held at the Institute for International Integration Studies in Trinity College Dublin in June 2005.

The papers address a wide variety of issues, but fall into three categories.

Białkowski et al. examine the extent and nature of spillovers in developed equity markets. They examine, using a Markov-switching model, the nature of these spillovers and contagions in calm and turbulent periods. Contrary to common assumption, they find that the dominance of the USA as a source of equity market influences is not clear. The US market is not the source of much of the measured contagion. Instead, regional linkages are at least as important. Continuing on the topic of equity market co-movements, Ciner finds that much of the existing literature on the strong NAFTA equity market linkages may overstate the real situation. His measures show increased convergence over the 1990s but he concludes that much of this is perhaps attributable to the boom in technology related stocks in the late 1990s.

Two papers explicitly look at integration in the real sector. Fernandez examines the APEC industrial sectors and demonstrates using a variety of measures that they show some but incomplete convergence of their business cycles, while Aizenmann and Noy show that FDI is more responsible for trade than vice versa in a large sample of OECD countries.

Finally, two other aspects of integration, the banking and cross listing issues are also addressed. Kleimeier and Sander examine the European experience in terms of wholesale banking, and show that a substantial element of the measured integration is part of a global phenomenon, and that banking markets in Europe are far from complete. O'Connor examines equity cross listing on US markets and presents evidence that this is partially a pull factor, to enhance reputation and governance, and partially a push factor in that companies with high-level governance tend to self-select to cross list their equity. 
Taken together the papers, we believe, provide a good overview of the state of the literature and research agenda in the area of real and financial integration as of 2005.

Guest Editor

Thomas Flavin

National University of Ireland, Maynooth, Ireland

Guest Editor Brian Lucey*

Institute for International Integration and School of Business, Room: 420, Áras an Phiarsaigh,

Trinity College, Dublin, Ireland

Guest Editor

Svitlana Voronkova

Institute for International Integration and School of Business, Trinity College, Dublin, Ireland

* Corresponding author. Tel.: +353 16081552 ; fax: +35316799503 .

E-mail address: brian.lucey@tcd.ie

(B. Lucey)

Available online 2 June 2006 